\title{
The arithmetic of health care
}

\section{Janice C. MacKinnon}

§ See related article page 600

T There is a simple arithmetic to the rising costs of health care, just as there was to the federal deficit in the 1990s. Health care costs are increasing at a faster rate than the revenue of any government in Canada, and the scramble by governments to fund health care means that other critical priorities are being underfunded. In Ontario, for example, because health care costs have increased by an average of $8 \%$ a year for the last 5 years, their share of the government spending pie has risen from $32 \%$ to $39 \%$; if interest costs are omitted, $46 \%$ of all Ontario spending is devoted to health care. These increases have come at the expense of funding for other priorities such as education, social programs and the environment. As Ontario Premier Dalton McGuinty explained, "there will come a time when the Ministry of Health is the only Ministry we can afford to have and we still won't be able to afford the Ministry of Health."

Despite ranking third in health care spending among 24 Organization for Economic Co-operation and Development countries, waiting lists in Canada are among the longest, and the country ranks 13 th in health outcomes and status, according to a recent Conference Board of Canada study. Canada's poor ranking is related to the fact that quality of life is twice as important as health services in determining health status. If health spending crowds out investments in education, childhood development, housing, environment and other measures that improve living conditions, then health status suffers.

The federal government has invested $\$ 65$ billion in health care in the last 5 years, and its health spending is increasing at almost $7 \%$ a year, a rate of increase that exceeds its rate of revenue growth. The provinces want more federal money, and Quebec has specified the amount that it believes the provinces need. If the federal government were to agree with Quebec's proposal, the result would be a cumulative federal deficit of more than $\$ 24$ billion in 5 years.

The federal government should not return to deficit, and it should ensure that other critical priorities are adequately funded. Thus, it should resist provincial demands to pay a fixed share of health care costs. It is also bad public policy to have one level of government administering health care programs and another level committed to paying a fixed share of the costs when it has limited administrative power to ensure cost-effectiveness. If the federal government agrees to an escalator - a fixed annual increase in federal funding - it should not exceed the rate of growth in federal revenue.
Even if the federal government were to commit $100 \%$ of its surpluses to health care, this would not change the fact that health care costs are unsustainable. What is required is an open-minded discussion of change, devoid of the standard rhetoric that attacks new ideas as "taxing the sick" or "privatizing the system." As well as discussing equity, we must also address quality and access: outdated equipment compromises quality, and long waiting lines negate access. And the idea that centralized engineering of the system will produce equity ignores the reality that those with the means jump the queue by going elsewhere for medical care.

Making the health care system more efficient may help to narrow the gap between increases in health care costs and government revenue; however, with our growing elderly population and the continuous development of new treatments, drugs and equipment, efficiencies alone will not make the health care system sustainable. The provinces, which have the constitutional responsibility to run the system and pay the majority of its costs, must find a new way to fund health care.

Provinces are already increasing health care taxes and fees, and some are following in the steps of Tommy Douglas, the Saskatchewan premier who founded medicare, by charging a health care premium. Assuming that provinces will continue to raise revenue for health care, what is the most effective way to do so?

A revenue measure to pay for health care should have the following characteristics. It should increase as costs increase: a simple tax increase will cover health care costs in the short term, but in the long term the rate of increase in health spending will surpass the rate of revenue growth. It should be related to income and ability to pay. It should be charged annually rather than when care is needed, so that people are not deterred from seeking necessary services.

What one pays for health care should also be related in some way to one's use of the system. Medicare was created to protect people from the misfortune of illness over which they have no control. However, although many medical conditions today are related to lifestyle choices, there are no incentives in our system to encourage people to take more responsibility for their health. As well, how can we expect patients to opt for more cost-effective medical choices, such as visiting a primary care physician or walk-in clinic rather than an emergency department, when they have no understanding of the comparative costs?

Linking what individuals pay to their use of health care services would also address the issue of intergenerational 
equity. Young people are already paying interest on government debt accumulated by their parents' generation and incurring personal debt to pay higher tuition costs for their education. To expect the same generation to pay higher taxes for health care services used primarily by older people is unfair. It will also hamper our ability to attract educated, skilled people as the prospect of labour shortages loom in the next decade.

Thus, making our health care system sustainable requires changes in the system and in the way that it is financed.
Janice MacKinnon is a professor of public policy at the University of Saskatchewan, Saskatoon. She was Saskatchewan finance minister in the Romanow government and is the author of Minding the Public Purse: The Fiscal Crisis, Political Tradeoffs and Canada's Future. This article is based on a study published by the Institute for Research on Public Policy (www.irpp.org).

Competing interests: None declared.

Correspondence to: Professor Janice C. MacKinnon, University of Saskatchewan, 101 President's Place, Saskatoon SK S7N 5C7; janice.mackinnon@usask.ca

\section{Canadian Medical Association}

2005 Special Awards - Call for Nominations

\section{Association médicale canadienne}

Prix spéciaux pour l'an 2005 - Appel de candidatures
The Canadian Medical Association invites nominations for the 2005 special awards.

- Medal of Honour

- F.N.G. Starr Award

- Medal of Service

- May Cohen Award for Women Mentors

- Sir Charles Tupper Award for Political Action

- Award for Excellence in Health Promotion

- CMA Award for Young Leaders

Refer to the "Awards from CMA" section on cma.ca for detailed criteria on each of the awards or contact the awards co-ordinator at $1800663-7336$, ext. 2280.

Nominations should be submitted to:

Chair, Committee on Archives c/o Committee Co-ordinator Strategic and Corporate Affairs Canadian Medical Association 1867 Alta Vista Drive Ottawa, ON K1G 3 Y6

Closing date for receipt of nominations is Nov. 30, 2004.
L'Association médicale canadienne sollicite des candidatures à ses prix spéciaux pour l'an 2005.

- Médaille d'honneur

- Prix F.N.G. Starr

- Médaille de service

- Prix May-Cohen pour femmes mentors

- Prix Sir-Charles-Tupper d'action politique

- Prix d'excellence de l'AMC en promotion de la santé

- Prix des jeunes chefs de file de l'AMC

Voir «Prix et distinctions de l'AMC» sur le site amc.ca pour les critères détaillés de chaque prix ou contacter la coordonnatrice des prix au $1800663-7336$, poste 2280 .

Les candidatures doivent être soumises au :

Président, Comité des archives a/s Coordonnatrice des comités Affaires générale et Stratégiques Association médicale canadienne 1867, promenade Alta Vista Ottawa (Ontario) K1G 3 Y6

Les candidatures doivent être présentées au plus tard le 30 novembre 2004. 